\title{
CORRIGENDUM
}

\section{Control of varicella in the post-vaccination era in Australia: a model-based assessment of catch-up and infant vaccination strategies for the future - CORRIGENDUM}

Z. GAO, J. G. WOOD, H. F. GIDDING, A. T. NEWALL, R. I. MENZIES,

H. WANG, P. B. MCINTYRE AND C. R. MACINTYRE

doi: http://dx.doi.org/10.1017/S0950268814002222. Published online: 15 September 2014.

In the above mentioned article [1] reference 35 was incorrect in the reference list. The correct reference is given below. The authors apologise for this error.

35. Ogunjimi B, et al. Herpes zoster risk reduction through exposure to chickenpox patients: a systematic multidisciplinary review. PLoS ONE 8(6): e66485. doi:10.1371/journal.pone.0066485.

\section{REFERENCE}

1. Gao Z, et al. Control of varicella in the post-vaccination era in Australia: a model-based assessment of catch-up and infant vaccination strategies for the future. Epidemiology and Infection. doi:10.1017/S0950268814002222. Published online: 15 September 2014. 